\title{
Grammatical Knowledge: Does It Affect Listening Comprehension?
}

\author{
Desi Surlitasari Dewi \\ English Education Department \\ University of Riau Kepulauan \\ belldaisy46@gmail.com
}

\begin{abstract}
Understanding an utterance is one of the goal in listening comprehension. An utterance consists of words and clauses that has a structure to bond them. It is interesting to find out whether the student's knowledge of grammatical structure has a role in their listening comprehension. Thus, the aim of this research was to find out whether any effect of grammatical knowledge towards student's listening comprehension. The data of student's listening comprehension were administered through a listening test of TOEFL by Phillips. While, the data for student's grammatical knowledge were assessed by grammar test by Azar. The participants of this study were eighty students of English Department Universitas Riau kepulauan taken by purposive sampling. Then, tukey test was used to analyze the data. The finding showed that student's grammatical knowledge had an effect on their listening comprehension. Thus, it is recommended for test takers not only to learn listening skills such as pronunciation, or vocabulary, but it is also important to master grammatical knowledge such as negative with comparative which have superlative meaning, double negative expression meaning statement positive, knowing the subjects in passive sentences, multiple nouns, and others to be able to increase listening comprehension.
\end{abstract}

Keywords: grammatical knowledge, listening comprehension

\section{INTRODUCTION}

The comprehension of listening as stated by Casperz and Stasinka (2015: 1) is the process of capturing words, listening, and understanding an utterance, not only what is spoken but also the implicit information conveyed in the utterance. Listening or listening comprehension, as opposed to hearing, is a process that requires a person to be mentally active (Low \& Sontag, 2013). Thus, it can be concluded that listening is an active process in one's mind to construct the meaning or meaning of a utterance being heard.

The things that usually hinder a person on the listening test, as Kassem (2015: 157) says are the anxiety of a person in the face of a listening test, a very limited listening time, and the speaking speed of the speaker considered too fast with a different accent to the 
listener, lack of knowledge of the topic being heard, and a lack of knowledge about the vocabulary used, and the structure of sentences containing certain meanings.

Furthermore, Kassem (2015) put forward an effective way of teaching listening:

1. In teaching listening, the teacher must be conscious or aware that learners are being prepared to learn to listen to foreign languages and be systematized

2. Listening instruction should be implemented in practice so as to provide real experience to learners.

3. Listening instruction should be planned. In teaching activities, there are some things that must be anticipated are the factors that inhibit effective listening.

Based on the above explanation, it is necessary to know what inhibiting factors that may affect someone's listening comprehension. Listening test used to measure listening ability of students in this study is Paper Based TOEFL Test Longman. There are three types of competences tested in the test, namely the ability to understand short conversations and the implications and the meanings of speakers' utterances. This test is in the form of multiple choice where each short conversation will be followed by one question. The second competence tested is the understanding of long conversations. This test serves to measure the student's competence to understand detailed information in long conversations. A long conversation will be followed by several questions. In both types of tests, the topic usually revolves around everyday life. While the latter is the ability to listen to a lecture or monologue. Almost the same as the long conversation, this test contains multiple multiple choice questions on a topic that measures the ability to listen with details of events or circumstances mentioned in the lecture. Topics in this type of test are more academic than those of the other two types of tests.

Test of English as Foreign Language or commonly known as TOEFL is a standardized test for knowing a person's ability to use English, both receptive and productive skill, which is an international language and one of the official languages of the United Nations, where many international activities are conducted in UK so it is important for academics to have the required TOEFL score to be able to be declared master English adequately.

In the era of globalization and free trade, having a high TOEFL score is a requirement to be able to study or work in other countries, especially those who use English as the language of instruction. Therefore, for university institutions, it is very important to prepare graduates who are highly competent in foreign language proficiency and able to compete in the world level, one of the benchmarks is having a high TOEFL score. 
One of the reasons why TOEFL tests are so important and global is that they serve to ensure that a person can understand English words, use them properly both orally and in writing, which is important when an academic wants to publicize his or her scientific work internationally . Someone who has a high TOEFL score certainly can understand the books in English so that it can have qualified references in doing research and writing scientific papers.

In TOEFL test, there are some tested capabilities such as the ability to understand reading in English, or known as reading test, and structure and written expression that measure a person's ability to recognize English according to the standard of writing In addition there is a listening test that is a test measure a person's ability to listen to English conversations, which contain several linguistic elements such as the use of phrases, two and three part verbs that have a different meaning from the basic word, the use of sentence wish and conditional phrase. In addition to short conversations, there are also long conversations and lectures containing some information at once which must be understood by the test taker.

The number of materials that must be mastered and understood by the students is one of the reasons for the low listening ability of English Education Study Program students. In listening to the TOEFL test, there are materials that contain elements of language structure, such as expressions containing negative meaning statements, passive sentences, causative verbs, conditional expressions such as the use of wish or if that have implicit meaning which is the opposite of the sentence spoken so that it requires the ability of students in understanding the meaning of these sentences to be able to listen properly.

Test of English as Foreign Language or commonly known as TOEFL is designed to measure the English proficiency of a person who is not a native English speaker. TOEFL has been accepted by over 6000 universities, campuses and official institutions in 130 countries. This test is also used by governments, scholarship organizers, and exchange lessons around the world. (Educational Testing Service, 2008: 1).

This test initially had five sections, but after extensive research in 1976, it was finally developed into three parts as we know them today. In recent years, TOEFL tests have grown to be more reflective of communicative ability and contain more constructed questions and directly measure one's ability to write and speak. This test may also provide information about a person's ability to use English in an academic setting. 
The TOEFL test has been developed into three types, the paper based TOEFL test (TOEFL PBT), the computer based TOEFL test (TOEFL CBT), and the latest is the internet based TOEFL test (TOEFL IBT) which was just developed in 2005. Unlike the two type of previous test, TOEFL IBT measures the ability of four English language skills namely, reading, listening, writing, and speaking.

In this research, the test used is a paper based TOEFL test (TOEFL PBT). Based on the explanation in Educational Testing Service (ETS, 2008: 12), there are three tested sections:

\section{Listening Comprehension}

It measures a person's ability to understand English spoken by a native speaker. The material tested includes vocabulary and phrases, as well as sentences with certain structures that are often used by native speakers in the conversation.

\section{Structure and Written Expression}

It measures the ability to recognize correct standard writing in English. The language used is a formal and standard language, and is not a conversational language. The topics in the sentences are usually academic but general in nature so that it can be understood by all circles in various fields of science.

\section{Reading Comprehension}

It measures a person's ability to understand short text. The topics of the reading are usually about academic life. Each text is followed by several questions, either directly or indirectly in the reading, so that the reader must recognize the implicit meaning in the reading. In addition, there are also questions about the meaning of unfamiliar words that must be known based on the context of reading.

The minimum value in Paper-based test is 310 and the maximum value that can be achieved is 677. (Educational Testing Service, 2008: 13)

\section{METHODOLOGY}

This research is a quantitative research which aims to find the difference between variables. There are two variables, namely grammatical knowledge as variable $\mathrm{X}$ and listening ability as variable $\mathrm{Y}$. This research was conducted in English Department of Universitas Riau Kepulauan.

Population is a generalization area consisting of objects / subjects that have certain qualities and characteristics set by the researchers to be studied and then drawn conclusions, while the sample is part of the number and characteristics possessed by the population. 
Population in this research is all students of study program of English Education University of Riau Islands, Kepulauan Riau, amounting to 328 students.

Due to the number of population, it is not possible to be studied as a whole (census), then, sampling technique was used in this study. Sampling method used in this research is purposive sampling. The sampling technique using purposive sampling was chosen because of the nature of the sample. The samples taken are final students (semester7 or 8) where they have mastered skill-skills in English and have received TOEFL teaching.

Data collection in this study using grammar and structure test to know the grammatical knowledge and TOEFL Listening Test to know listening ability of students. And documentation techniques to record all activities undertaken in the research. Prior to the data collection, we did try out the research instrument (grammar and structure test) to determine the validity and reliability of the research instrument by using pearson product moment to measure the validity of the question and KR-20 to determine the reliability of the test.

After data collection, firstly tested normality and homogeneity to find out that the sample data is normal and homogeneous. The data are grammar and structure values of grammar tests (Azar, 2007) that represent grammatical knowledge and TOEFL Listening Test which represents Listening comprehension. Data then processed by using t-test to know the significance influence of variable $\mathrm{X}$ toward variable $\mathrm{Y}$.

\section{RESULTS}

Based on the data obtained from the tests of grammatical knowledge and listening tests, then $t_{\text {test }}$ done to determine the effect of grammatical knowledge to listening score with the formula as follows.

$$
\begin{aligned}
& t=\frac{50.17-44.67}{\sqrt{\frac{45.66}{30}+\frac{51.64}{30}}} \\
& t=\frac{5.50}{\sqrt{1.522+1.721}} \\
& t=\frac{5.50}{\sqrt{3.243}} \\
& t=\frac{5.50}{1 . .80}
\end{aligned}
$$




$$
t=3.056
$$

Based on the calculation, the result shows that the $t_{\text {test }}$ of 3.056 is bigger than the $t_{\text {table }}$ of 2.04 with the significance level of 5\%, thus, it can be concluded that the grammatical knowledge mastered by students affects their listening comprehension.

\section{DISCUSSION}

The result of $\mathrm{t}_{\text {test }}$ is 3.056 bigger than $\mathrm{t}_{\text {table }}(2.04)$ by the level of significance of $5 \%$, it can be concluded that the grammatical of students of English Department affect their listening comprehension. It means that students having high grammatical knowledge have a higher TOEFL listening score than those having lower grammatical knowledge. It could happen because in the listening test on the TOEFL test, there are some materials that meaning may not be understood without understanding the structure of the sentence, such as negatives with comparatives that contain superlative meaning.

Based on the results of research that grammatical knowledge affect listening comprehension, it is recommended for test takers not only to learn listening skills such as pronunciation, or vocabulary, but it is also important to master grammatical knowledge such as negative with comparative which have superlative meaning, double negative expression meaning statement positive, knowing the subjects in passive sentences, multiple nouns, and others to be able to increase listening comprehension.

\section{REFERENCES}

Azar, B. (2007). Grammar-based teaching: A practitioner's perspective. TESL-EJ, 11 (2).

Caspersz, Donella \& Stasinka, Ania. (2015). Can we teach effective listening? An exploratory study. Journal of University Teaching and learning Practice, vol. 12, Issue 4, Article 2, pp. 1-13.

Educational Testing Service. (2008). Test and score data summary for TOEFL internet based and paper based tests. Princeton: Educational Testing Service Publisher

Kassem. (2015). English Language Teaching Journal. Vol. 8, No. 2; 2015 p. 157. Retrieved from: http://www.ccsenet.org/elt

Low, B E \& Sonntag, E. (2013). Towards a pedagogy of listening: Teaching and learning from life stories of human rights violations. Journal of Curriculum Studies, vol. 45, no. 6, pp. 768-789. 